\title{
Information Management and Computer Science (IMCS)
}

DOI : http://doi.org/10.26480/imcs.02.2019.04.09

ZIBELINE INTTERNATIIONAL

Online ISSN : 2616-5961

CODEN : IMCSBZ

\section{RESEARCH ARTICLE}

\section{SUSTAINING THE SUPPLY CHAIN MANAGEMENT SYSTEM OF A MULTI-PURPOSE COOPERATIVE IN TIAONG, QUEZON}

\author{
Janzene L. Aguilar \\ San Pablo Colleges, San Pablo City. \\ *Corresponding Author Email: janzeneaguilar02@gmail.com
}

This is an open access article distributed under the Creative Commons Attribution License, which permits unrestricted use, distribution, and reproduction in any medium, provided the original work is properly cited.

\section{ARTICLE DETAILS}

\section{Article History:}

Received 26 August 2019

Accepted 29 September 2019

Available online 24 October 2019

\begin{abstract}
This study primarily intended to analyze the supply chain management of Luntian Multi-Purpose Cooperative in Tiaong Quezon, to determine the problems that the cooperative are encountering and to furnish recommendations. For this research, descriptive method and inferential method were used. The researcher gathered information from 10 members, 3 suppliers and 9 from the management of the Luntian Multipurpose Cooperative for a total of twentytwo (22) respondents. The questionnaires were directly administered and retrieved from the respondents. The data collected were gathered and analyzed using the percentage, frequency distribution and weighted mean. The study revealed that the factors that gained the lowest ratings were the location where to order/purchase, new product development, space utilization, accurate inventory information, inventory location (proper shelving) and machine efficiency. In the problems encountered, the researcher recommends that Luntian MPC should solicit suggestions from their customers and members on how to innovate and further improve the cooperative operations according to their needs. The following are the suggestions given by the customers: to have branches in different places, to standardize the processes in the supply chain management processes, to ensure the reliability of the supplier, to have automated machines, to initiate activity for suppliers, members and management that will build rapport and trust within the cooperative and lastly, to purchase a vehicle for the delivery of the products to provide better service and ease to their customers.
\end{abstract}

\section{KEYWORDS}

supply chain management, multipurpose cooperative.

\section{INTRODUCTION}

In every business, there is always an aspect of supply chain. Supply chain management is often seen as an integral part of business for its success and to fulfill its customer satisfaction. In this modern era, businesses need to have a sense of efficient management and revision of the existing supply chain so it stays ahead of the changing trends that this world brings. This study focused on the analysis of the Supply Chain Management of Luntian MPC. It sought to determine and evaluate the degree of importance of the different supply chain management factors and to know the perception of its members, suppliers and management in terms of the management systems that made up the whole supply chain management.

According to a study, supply chain management is the active management of supply chain activities to maximize customer value and achieve a sustainable competitive advantage [1]. It represents a conscious effort by the supply chain firms to develop and run supply chains in the most effective \& efficient ways possible. Supply chain activities cover everything from product development, sourcing, production, and logistics, as well as the information systems needed to coordinate these activities. The organizations that make up the supply chain are "linked" together through physical flows and information flows. Physical flows involve the transformation, movement, and storage of goods and materials. They are the most visible piece of the supply chain. But just as important are information flows, they allow the various supply chain partners to coordinate their long-term plans, and to control the day-to-day flow of goods and material up and down the supply chain [1].

The Luntian Multi-Purpose Cooperative which is located in Lalig, Tiaong Quezon is composed of members who are considered as the owners of the cooperative. The Luntian MPC is involved in feed milling, hog fattening and has a meat shop of its own. Feed milling is the main business of Luntian MPC. It produces two brand names of feeds, the Luntian (premium brand) and Talisay. The cooperative claims lower prices than most commercial feed brands sold in Tiaong, Quezon. The hog fattening of Luntian MPC is the system of hog raising wherein the members provide for the piglets, while the cooperative provides for the feeds and veterinary medicines. The cooperative helps the member in selling the pig and after computing for all the cost of the feeds and medicines shouldered by the cooperative, the earnings/profit are given to the member. There is also a meat shop to provide more services among its members and it produces nine different kinds of processed meats: cured bacon, embutido, ham, hamburger patties, siomai, tocino, skinless longganisa and regular longganisa.

It is known that livestock raising and the consumption of animal products make a crucial contribution to the economic and nutritional well-being of millions of people around the world and with that, the operations of Luntian MPC, especially for its members are vital. At the present time, the Luntian MPC is facing a problem with regard to their production due to lack of machines. The demand for feeds fromits members and customers are rapidly increasing and the number of feeds produced by the machine is not enough to meet the demand. Due to that, the workers of Luntian need to add shift in their working hours in order to meet the demand.

The interest in better management of supply chains has expanded rapidly over the years in line with increased consumer demand for quality, convenience and novelty. Satisfying these consumer needs and demands would only be realized by coordinating management of the supply chain from farm to retail shelf.

These interests in supply chain teamed up with the interest on the operations of production of feeds from raw materials to end consumers bring the researcher to the decision to study this topic in a broader and profound aspect. It is believed that this study will help the researcher utilize their accumulated knowledge and bring them closer to the business world. 


\section{REVIEW OF RELATED LITERATURE}

According a study, cooperatives provide their members strength in numbers. They pool resources of their varied memberships and they provide a ready venue for exchange of ideas and skills [2]. More importantly, in coming together for a common cause, cooperatives increase the intellectual capital of the members thus providing opportunities where none existed. Opportunities are indeed when cooperatives perform and live up to their real mission. In short, the cooperative as a movement is truly the only practical tool to achieve units of purpose and thus secure the "Power of One". The official of Cooperative Development Authority (CDA), a government body that supervises cooperatives, define cooperative as "a duly registered association of persons, with common bond of interest who have voluntarily joined together to achieve a lawful common social or economic and making equitable contributions to the capital required and accepting a fair share of the risks and benefits of the undertaking in accordance with universally acceptable cooperative principles."

According the cooperative system is probably the most misunderstood economic system today [3]. Many are confused with its nature, its principles, doctrines and practices. They suspect that cooperation is socialistic and when people re drawn into it, they are only being sucked farther toward the left. Many believe that it is anti- capital and it allowed to prosper it would necessarily destroy the present economic structure. And still others believe that cooperation is basically faulty and impractical, which attribute to the terrible failures of many cooperative societies that have been organized in this country.

Cooperatives, by definition, are controlled by members. By belonging to a cooperative, farmers subscribe to a share of the capital and participate, as partners, in the running of the cooperative according to the democratic principal of "one man one vote". Now, certain studies have noted a decrease in members' participation in the democratic life of cooperatives even if these are indeed their "own". Whether members behave opportunistically or as free-riders, the main reason for this change in farmers' behavior seems to lie in the phenomenon of concentration and restructuring of agricultural cooperatives. In certain cases, farmers find themselves in huge cooperative groups; these are diversified and international with strategy so complex that farmers find it difficult to understand [4]. In view of their members' detachment, it is important that cooperatives understand such attitudes and behaviors, for members contribute to the cooperatives' performance. The success of a cooperative depends on the degree of participation of its members, as shown in Österberg and Nilsson's study carried out with over 2000 Swedish farmers. As voluntary organizations, cooperatives are based on a democratic decision-making process that rests upon collective participation, balance of countervailing powers, and cohesion among members.

Supply chain management (SCM) refers to the management of the entire set of production, distribution, and marketing processes, which supplies consumers with a desired product. Some researchers define a supply chain as a set of interdependent companies that work closely together to manage the flow of goods and services along the value-added chain in order to realize superior customer value at the lowest possible cost. Fundamentally, SCM is a process that seeks to integrate supply and demand through coordinating the activities of many independent actors in the procurement, production and distribution of food products.

Interest in better management of supply chains has expanded in line with increased consumer demand for quality, convenience, novelty and other non-food attributes in the food products they buy, together with an increased concern over food-product integrity and safety. Satisfying these consumer demands can be achieved only by coordinator management of the supply chain from farm to retail shelf [5]. In developing countries such as the Philippines, supply chains are typically long and fragmented, involving multiple small hold producers delivering produce to collectors. The produce then moves to several layers of traders, wholesalers and retailers. These chains are flows and a predominance of spot transactions over longer-term buyer-seller relationships.

Some researchers aptly describe the major SCM challenges in the context of a developing country. First, SCM requires producers either directly or indirectly, to deliver to consumers the food that fulfills their expectations. But herein lies the first major obstacle: do producers know what consumers want? In most instances, small hold farmers do not transact directly with the ultimate buyer: rather, they sell their produce to a downstream market intermediary who is just one of many in a long and complex process of exchange [6]. Secondly, the increasing role of institutional markets in food retail is giving rise to another obstacle: how can small hold farmers coordinate their activities to meet their needs of the institutional market? This inevitably calls for strong collaborative marketing groups or for downstream marketing intermediaries to exert control through contract farming. Either way, it becomes mandatory to standardize production systems and to implement quality standards. Herein arises the third major constraint: how is it possible to introduce and to implement quality assurance systems for small hold farmers?

According to book of Operation and Supply Management, there are four types of supply chain: (a) Efficient supply chains that utilize strategies aimed at creating the highest cost efficiency. For such efficiencies to be achieved, non-value-added activities should be eliminated, scale economies should be pursued, optimization techniques should be deployed to get the best capacity utilization in production and distribution, and information linkages should be established to ensure the most efficient, accurate, and most cost effective transmission of information across the supply chain; (b) Risk-hedging supply chain are supply chain that utilized strategies aimed at pooling and sharing resources in a supply chain so that the risks in supply chain disruption can be shared [7].

A single entity in s supply chain can be vulnerable to supply disruptions, but if there is more than one supply source or alternative supply resources are available, then risk of disruption is reduced.; (c) Responsive supply chain utilize strategies aimed at being responsive and flexible to the changing and diverse needs of the customers. To be responsive, companies use to build-to order and mass customization processes as a means to meet the specific requirements of customers; (d) Agile supply chains utilize strategies aimed at being responsive and flexible to customer need, while the risks of supply shortages or disruptions are hedged by pooling inventory and other capacity resources. These supply chains essentially have strategies in place that combine the strengths of "hedged" and "responsive" supply chain. They are agile because they have ability to be responsive to the changing, diverse, and unpredictable demands of customers on the front end, while minimizing the back-end risks of supply disruptions.

The main goal of SCM is to maximize value for the consumer through coordination and control of all activities within a supply chain. In a study state that the activities within the supply chain occur across multiple organizations and geographic locations. It focuses on four management activities; determining market requirements; establishing and managing supply chain relationships; managing and sharing information; and, managing material production and distribution.

\section{RESEARCH METHODOLOGY}

This study used descriptive research design which focuses on describing the supply chain management of Luntian MPC and the characteristics of variables in particular instances. Inferential method of research was also in this study. Information was gathered from 10 members, 3 suppliers and 9 from the management of the Luntian Multipurpose Cooperative for a total of twenty-two (22) respondents [8]. Purposive sampling is used which is a type of probability sampling. In non-probability sampling, there is no system in selecting the sample. The researcher used survey questionnaires. The gathering of primary data and pre-interview for the initial data gathering of information about the topic. Questionnaires were used to have information regarding the process of supply chain management in Luntian MPC and the problems they are encountering [9] It was constructed in a manner that the respondents can easily choose upon the given choices. The choices were arranged in in a five-point Likert scale. The ratings and weighted mean of the participants were ascertained with the use of the scale given below:

Table 1: Descriptive Rating Table

\begin{tabular}{|l|l|l|l|l|}
\hline SCALE & Range & $\begin{array}{l}\text { Verbal } \\
\text { Description }\end{array}$ & $\begin{array}{l}\text { Verbal } \\
\text { Description }\end{array}$ & $\begin{array}{l}\text { Verbal } \\
\text { Description }\end{array}$ \\
\hline 5 & $4.50-5.00$ & $\begin{array}{l}\text { Very } \\
\text { Important }\end{array}$ & Excellent & Very Strong \\
\hline 4 & $3.50-4.49$ & Important & Very Good & Strong \\
\hline 3 & $2.50-3.49$ & $\begin{array}{l}\text { Moderately } \\
\text { Important }\end{array}$ & Good & Normal \\
\hline 2 & $1.50-2.49$ & Unimportant & Fair & Weak \\
\hline 2 & $1.00-1.49$ & $\begin{array}{l}\text { Very } \\
\text { Unimportant }\end{array}$ & $\begin{array}{l}\text { Needs } \\
\text { Improvement }\end{array}$ & Very Weak \\
\hline
\end{tabular}




\section{RESULTS AND DISCUSSION}

Table 2: Degree of Importance of the Different Supply Chain Management Factors of Luntian MPC in terms of Developing Supply Chain Management System according to its supplier, management and member

\begin{tabular}{|c|c|c|c|c|c|c|}
\hline & \multicolumn{2}{|c|}{ SUPPLIER } & \multicolumn{2}{|c|}{ MANAGEMENT } & \multicolumn{2}{|c|}{ MEMBER } \\
\hline & $\begin{array}{l}\text { WEIGHTED } \\
\text { MEAN }\end{array}$ & $\begin{array}{c}\text { VERBAL } \\
\text { INTERPRETA- } \\
\text { TION }\end{array}$ & $\begin{array}{l}\text { WEIGHTED } \\
\text { MEAN }\end{array}$ & $\begin{array}{c}\text { VERBAL } \\
\text { INTERPRETA- } \\
\text { TION }\end{array}$ & $\begin{array}{l}\text { WEIGHTED } \\
\text { MEAN }\end{array}$ & $\begin{array}{c}\text { VERBAL } \\
\text { INTERPRETA- } \\
\text { TION }\end{array}$ \\
\hline $\begin{array}{l}\text { Reliable delivery } \\
\text { date of goods }\end{array}$ & 5.00 & Very Important & 3.40 & $\begin{array}{l}\text { Moderately } \\
\text { Important }\end{array}$ & 4.56 & Very Important \\
\hline $\begin{array}{l}\text { Accurate Order } \\
\text { fulfillment }\end{array}$ & 5.00 & Very Important & 3.60 & Important & 4.67 & Very Important \\
\hline $\begin{array}{l}\text { Delivery at specified } \\
\text { time }\end{array}$ & 5.00 & Very Important & 3.60 & Important & 4.67 & Very Important \\
\hline $\begin{array}{l}\text { Handling of } \\
\text { complaints }\end{array}$ & 5.00 & Very Important & 3.80 & Important & 4.67 & Very Important \\
\hline Quality of materials & 5.00 & Very Important & 4.10 & Important & 4.78 & Very Important \\
\hline Quality of service & 5.00 & Very Important & 4.20 & Important & 4.78 & Very Important \\
\hline Product availability & 5.00 & Very Important & 4.00 & Important & 4.78 & Very Important \\
\hline $\begin{array}{l}\text { Top management } \\
\text { support in terms of } \\
\text { promo, or discount }\end{array}$ & 5.00 & Very Important & 3.40 & $\begin{array}{l}\text { Moderately } \\
\text { Important }\end{array}$ & 4.56 & Very Important \\
\hline $\begin{array}{l}\text { Trust in Luntian } \\
\text { MPC }\end{array}$ & 5.00 & Very Important & 4.40 & Important & 4.89 & Very Important \\
\hline $\begin{array}{l}\text { Mutual interest in } \\
\text { terms of pricing }\end{array}$ & 5.00 & Very Important & 3.80 & Important & 4.67 & Very Important \\
\hline $\begin{array}{l}\text { Closer links between } \\
\text { demand/ supply }\end{array}$ & 5.00 & Very Important & 4.30 & Important & 4.44 & Important \\
\hline $\begin{array}{l}\text { Free flow of } \\
\text { information of the } \\
\text { status of operation }\end{array}$ & 5.00 & Very Important & 3.80 & Important & 4.56 & Very Important \\
\hline $\begin{array}{l}\text { Improved customer } \\
\text { service }\end{array}$ & 5.00 & Very Important & 4.30 & Important & 4.44 & Important \\
\hline $\begin{array}{l}\text { Overall supply chain } \\
\text { reduction }\end{array}$ & 5.00 & Very Important & 3.70 & Important & 4.56 & Very Important \\
\hline $\begin{array}{l}\text { Increased } \\
\text { profitability }\end{array}$ & 5.00 & Very Important & 3.80 & Important & 4.44 & Important \\
\hline $\begin{array}{l}\text { Increased market } \\
\text { competitiveness }\end{array}$ & 5.00 & Very Important & 3.90 & Important & 4.33 & Important \\
\hline $\begin{array}{l}\text { Cost reductions } \\
\text { within the } \\
\text { organizations }\end{array}$ & 5.00 & Very Important & 4.20 & Important & 4.33 & Important \\
\hline Benefits to the client & 5.00 & Very Important & 4.00 & Important & 4.22 & Important \\
\hline $\begin{array}{l}\text { Benefits to your } \\
\text { supplier }\end{array}$ & 5.00 & Very Important & 3.90 & Important & 4.00 & Important \\
\hline $\begin{array}{l}\text { Improved quality } \\
\text { assurance }\end{array}$ & 5.00 & Very Important & 4.30 & Important & 4.33 & Important \\
\hline $\begin{array}{l}\text { Average Weighted } \\
\text { Mean }\end{array}$ & 5.00 & Very Important & 3.93 & Important & 4.53 & $\begin{array}{l}\text { Very } \\
\text { Important }\end{array}$ \\
\hline
\end{tabular}

On the degree of the importance of the different supply chain management factors of the Luntian MPC in developing supply chain management system, in the point of view of the suppliers, they consider every factor as very important. According to the best companies around the world are discovering a powerful new source of competitive advantage. It's called supply-chain management and it encompasses all of those integrated activities that bring product to market and create satisfied customers [10] The Supply Chain Management Program integrates topics from manufacturing operations, purchasing, transportation, and physical distribution into a unified program. Successful supply chain management, then, coordinates and integrates all of these activities into a seamless process. It embraces and links all of the partners in the chain.

Table 3: Perception of Suppliers, Management and Member in the Order Management Performance of Luntian MPC

\begin{tabular}{|l|c|c|c|c|c|c|}
\hline & \multicolumn{2}{|c|}{ SUPPLIER } & \multicolumn{2}{c|}{ MANAGEMENT } & \multicolumn{2}{c|}{ MEMBER } \\
\hline & $\begin{array}{c}\text { WEIGHTED } \\
\text { MEAN }\end{array}$ & $\begin{array}{c}\text { VERBAL } \\
\text { INTERPRETA- } \\
\text { TION }\end{array}$ & $\begin{array}{c}\text { WEIGHTED } \\
\text { MEAN }\end{array}$ & $\begin{array}{c}\text { VERBAL } \\
\text { INTERPRETA- } \\
\text { TION }\end{array}$ & $\begin{array}{c}\text { WEIGHTED } \\
\text { MEAN }\end{array}$ & $\begin{array}{c}\text { VERBAL } \\
\text { INTERPRETA- } \\
\text { TION }\end{array}$ \\
\hline Fast Ordering Process & 4.00 & Very Good & 3.78 & Very Good & 3.50 & Very Good \\
\hline $\begin{array}{l}\text { Accurate Order fulfillment } \\
\text { (if your order is correctly } \\
\text { fulfilled) }\end{array}$ & 4.00 & Very Good & 4.00 & Very Good & 3.30 & Good \\
\hline
\end{tabular}




\begin{tabular}{|l|c|c|c|c|c|c|}
\hline $\begin{array}{l}\text { Location where to } \\
\text { order/purchase }\end{array}$ & 4.00 & $\begin{array}{c}\text { Very G } \\
\text { ood }\end{array}$ & 4.00 & Very Good & 3.20 & Good \\
\hline Handling of complaints & 4.00 & Very Good & 3.89 & Very Good & 3.50 & Very Good \\
\hline $\begin{array}{l}\text { Purchasing (if it is smooth } \\
\text { flowing) }\end{array}$ & 4.33 & Very Good & 3.67 & Very Good & 3.40 & Good \\
\hline $\begin{array}{l}\text { Responds rapidly to } \\
\text { unexpected demand change }\end{array}$ & 4.00 & Very Good & 3.78 & Very Good & 3.50 & Very Good \\
\hline Average Weighted Mean & $\mathbf{4 . 0 6}$ & Very Good & $\mathbf{3 . 8 5}$ & Very Good & $\mathbf{3 . 4 0}$ & $\mathbf{G o o d}$ \\
\hline
\end{tabular}

In the order management of Luntian MPC in the perception of the supplier and management, Luntian MPC has a very good order management. But for the perceptions of the members, it has a good order management.
According to a well implemented order management include improved sales visibility, improved customer relations and efficient order processing with a minimum of delays and back-orders [11].

Table 4: Perception of Suppliers, Management, Member in the Production Management Performance of Luntian MPC

\begin{tabular}{|c|c|c|c|c|c|c|}
\hline & \multicolumn{2}{|c|}{ SUPPLIER } & \multicolumn{2}{|c|}{ MANAGEMENT } & \multicolumn{2}{|c|}{ MEMBER } \\
\hline & $\begin{array}{l}\text { WEIGHTED } \\
\text { MEAN }\end{array}$ & $\begin{array}{c}\text { VERBAL } \\
\text { INTERPRETA- } \\
\text { TION }\end{array}$ & $\begin{array}{l}\text { WEIGHTED } \\
\text { MEAN }\end{array}$ & $\begin{array}{c}\text { VERBAL } \\
\text { INTERPRETA- } \\
\text { TION }\end{array}$ & $\begin{array}{l}\text { WEIGHTED } \\
\text { MEAN }\end{array}$ & $\begin{array}{c}\text { VERBAL } \\
\text { INTERPRETA- } \\
\text { TION }\end{array}$ \\
\hline Quality of Materials & 4.33 & Very Good & 4.22 & Very Good & 3.60 & Very Good \\
\hline Quality of Service & 4.33 & Very Good & 4.11 & Very Good & 3.70 & Very Good \\
\hline $\begin{array}{l}\text { Reliability of manpower in } \\
\text { the production process }\end{array}$ & 4.33 & Very Good & 4.11 & Very Good & 3.60 & Very Good \\
\hline \multicolumn{7}{|l|}{$\begin{array}{l}\text { Reliability of supply in } \\
\text { terms of: }\end{array}$} \\
\hline${ }^{*}$ Feeds & 4.67 & Excellent & 4.11 & Very Good & 3.50 & Very Good \\
\hline *Hog Fattening & 4.33 & Very Good & 4.11 & Very Good & 3.50 & Very Good \\
\hline${ }^{*}$ Meat & 4.33 & Very Good & 4.33 & Very Good & 3.80 & Very Good \\
\hline Compete based on quality & 4.67 & Excellent & 4.11 & Very Good & 3.90 & Very Good \\
\hline $\begin{array}{l}\text { Offer products that are } \\
\text { highly reliable }\end{array}$ & 4.67 & Excellent & 4.11 & Very Good & 3.20 & Good \\
\hline Average Weighted Mean & 4.46 & Very Good & 4.15 & Very Good & 3.60 & Very Good \\
\hline
\end{tabular}

In terms of the production management, Luntian MPC also has a very good production management as perceived by its supplier, member and management. According to the book of "Supply Chain Logistic Management" effective production planning results in a time sequenced plan to manufacture the correct items efficiently while operating within facility equipment and labor constraints [12]. Production planning identifies the item that should be produced in anticipation of need to remain within production constraints and yet minimize inventory.

Table 5: Perception of Suppliers, Management, Member in the Warehouse Management Performance of Luntian MPC

\begin{tabular}{|c|c|c|c|c|c|c|}
\hline & \multicolumn{2}{|c|}{$\begin{array}{l}\text { SUPPLIER } \\
\end{array}$} & \multicolumn{2}{|c|}{ MANAGEMENT } & \multicolumn{2}{|c|}{ MEMBER } \\
\hline & $\begin{array}{l}\text { WEIGHTED } \\
\text { MEAN }\end{array}$ & $\begin{array}{c}\text { VERBAL } \\
\text { INTERPRETA- } \\
\text { TION }\end{array}$ & $\begin{array}{l}\text { WEIGHTED } \\
\text { MEAN }\end{array}$ & $\begin{array}{c}\text { VERBAL } \\
\text { INTERPRETA- } \\
\text { TION }\end{array}$ & $\begin{array}{l}\text { WEIGHTED } \\
\text { MEAN }\end{array}$ & $\begin{array}{c}\text { VERBAL } \\
\text { INTERPRETA- } \\
\text { TION }\end{array}$ \\
\hline Security of the products & 4.00 & Very Good & 4.22 & Very Good & 3.30 & Good \\
\hline $\begin{array}{l}\text { Handling of materials (if it } \\
\text { is handled with care) }\end{array}$ & 4.33 & Very Good & 4.33 & Very Good & 3.40 & Good \\
\hline $\begin{array}{l}\text { Space Utilization (if the } \\
\text { space is properly utilized) }\end{array}$ & 4.00 & Very Good & 4.00 & Very Good & 3.00 & Good \\
\hline $\begin{array}{l}\text { Picking optimization (can } \\
\text { the product be easily find } \\
\text { in the warehouse }\end{array}$ & 4.00 & Very Good & 3.89 & Very Good & 3.70 & Very Good \\
\hline $\begin{array}{l}\text { Proper warehousing of } \\
\text { the products }\end{array}$ & 4.00 & Very Good & 3.89 & Very Good & 3.80 & Very Good \\
\hline Proper Sanitation & 4.00 & Very Good & 3.78 & Very Good & 3.90 & Very Good \\
\hline Average Weighted Mean & 4.06 & Very Good & 4.02 & Very Good & 3.52 & Very Good \\
\hline
\end{tabular}

The Luntian MPC's warehouse management is very good according to its suppliers, members and management. Bowersox mentioned that warehousing exist to support marketing, manufacturing and distribution efficiency [13].

Table 6: Perception of Suppliers, Management, Member in the Inventory Management Performance of Luntian MPC

\begin{tabular}{|c|c|c|c|c|c|c|}
\hline & \multicolumn{2}{|c|}{ SUPPLIER } & \multicolumn{2}{|c|}{ MANAGEMENT } & \multicolumn{2}{|c|}{ MEMBER } \\
\hline & $\begin{array}{c}\text { WEIGHTED } \\
\text { MEAN }\end{array}$ & $\begin{array}{c}\text { VERBAL } \\
\text { INTERPRETATION }\end{array}$ & $\begin{array}{c}\text { WEIGHTED } \\
\text { MEAN }\end{array}$ & $\begin{array}{c}\text { VERBAL } \\
\text { INTERPRETA- } \\
\text { TION }\end{array}$ & $\begin{array}{c}\text { WEIGHTED } \\
\text { MEAN }\end{array}$ & $\begin{array}{c}\text { VERBAL } \\
\text { INTERPRETA- } \\
\text { TION }\end{array}$ \\
\hline
\end{tabular}




\begin{tabular}{|c|c|c|c|c|c|c|}
\hline $\begin{array}{l}\text { Accurate count of stocks/ } \\
\text { Accurate inventory } \\
\text { information }\end{array}$ & 4.00 & Very Good & 3.56 & Very Good & 3.30 & Good \\
\hline $\begin{array}{l}\text { Forecasting demand of } \\
\text { Luntian Products }\end{array}$ & 4.33 & Very Good & 3.78 & Very Good & 3.60 & Very Good \\
\hline $\begin{array}{l}\text { Inventory location (proper } \\
\text { shelving) }\end{array}$ & 4.00 & Very Good & 3.67 & Very Good & 3.20 & Good \\
\hline \multicolumn{7}{|l|}{$\begin{array}{l}\text { Availability of stocks in } \\
\text { terms of: }\end{array}$} \\
\hline \multirow{3}{*}{$\begin{array}{l}\text { *Feeds } \\
\text { *Hog Fattening } \\
\text { *Meat (Meat Shop) }\end{array}$} & 4.33 & Very Good & 3.78 & Very Good & 3.80 & Very Good \\
\hline & 4.33 & Very Good & 3.67 & Very Good & 3.70 & Very Good \\
\hline & 4.33 & Very Good & 3.78 & Very Good & 3.90 & Very Good \\
\hline Average Weighted Mean & 4.22 & Very Good & 3.71 & Very Good & 3.58 & Very Good \\
\hline
\end{tabular}

Regarding Luntian MPC's inventory management from the point of view of the suppliers, members and management, its performance was also very good. In a study has been discusses that good inventory management is important for the successful operation of most businesses and their supply chains [14]. Poor inventory management hampers operations diminishes customer satisfaction and increases operating costs. Thus, inventories are a vital part of business and they are not only necessary for operations, but also contribute to customer satisfaction.

Table 7: Perception of Suppliers, Management, Member in the Manufacturing Management Performance of Luntian MPC

\begin{tabular}{|l|c|c|c|c|c|c|}
\hline & \multicolumn{2}{|c|}{ SUPPLIER } & \multicolumn{2}{c|}{ MANAGEMENT } & \multicolumn{2}{c|}{ MEMBER } \\
\hline MEAT & $\begin{array}{c}\text { VERBAL } \\
\text { INTERPRETA- } \\
\text { TION }\end{array}$ & $\begin{array}{c}\text { WEIGHTED } \\
\text { MEAN }\end{array}$ & $\begin{array}{c}\text { VERBAL } \\
\text { INTERPRETA- } \\
\text { TION }\end{array}$ & $\begin{array}{c}\text { WEIGHTED } \\
\text { MEAN }\end{array}$ & $\begin{array}{c}\text { VERBAL } \\
\text { INTERPRETA- } \\
\text { TION }\end{array}$ \\
\hline $\begin{array}{l}\text { Time Management in the } \\
\text { manufacturing process }\end{array}$ & 3.67 & Very Good & 3.78 & Very Good & 3.50 & Very Good \\
\hline $\begin{array}{l}\text { Reliability of manpower/ } \\
\text { workers }\end{array}$ & 4.00 & Very Good & 3.78 & Very Good & 3.50 & Very Good \\
\hline Training and inspections & 4.00 & Very Good & 3.56 & Very Good & 3.80 & Very Good \\
\hline $\begin{array}{l}\text { Balancing between } \\
\text { demand and supply }\end{array}$ & 4.33 & Very Good & 3.78 & Very Good & 3.40 & Good \\
\hline $\begin{array}{l}\text { Accurate manufacturing } \\
\text { date on the products }\end{array}$ & 4.33 & Very Good & 3.78 & Very Good & 3.80 & Very Good \\
\hline $\begin{array}{l}\text { Enough machine to } \\
\text { produce the demand }\end{array}$ & 4.00 & Very Good & 3.67 & Very Good & 3.80 & Very Good \\
\hline Machine Efficiency & 4.00 & Very Good & 3.67 & Very Good & 3.10 & Good \\
\hline Average Weighted Mean & $\mathbf{4 . 0 0}$ & Very Good & $\mathbf{3 . 7 2}$ & Very Good & $\mathbf{3 . 5 6}$ & Very Good \\
\hline
\end{tabular}

According to Luntian MPC's suppliers, members and management, it has a very good manufacturing management. A group researchers, state that manufacturing planning and control system is concerned with planning and controlling all aspects of manufacturing including managing materials, scheduling machines and people and coordinating supplies and key customers [15]. The development of an effective manufacturing planning and control system is key to the success of any goods producing company.

Table 7: Perception of Suppliers, Management, Member in the Distribution Planning Performance of Luntian MPC

\begin{tabular}{|l|c|c|c|c|c|c|}
\hline & \multicolumn{2}{|c|}{ SUPPLIER } & \multicolumn{2}{c|}{ MANAGEMENT } & \multicolumn{2}{c|}{ MEMBER } \\
\hline & $\begin{array}{c}\text { WEIGHTED } \\
\text { MEAN }\end{array}$ & $\begin{array}{c}\text { VERBAL } \\
\text { INTERPRETA- } \\
\text { TION }\end{array}$ & $\begin{array}{c}\text { WEIGHTED } \\
\text { MEAN }\end{array}$ & $\begin{array}{c}\text { VERBAL } \\
\text { INTERPRETA- } \\
\text { TION }\end{array}$ & $\begin{array}{c}\text { WEIGHTED } \\
\text { MEAN }\end{array}$ & $\begin{array}{c}\text { VERBAL } \\
\text { INTERPRTA- } \\
\text { TION }\end{array}$ \\
\hline On time delivery & 4.33 & Very Good & 3.67 & Very Good & 3.70 & Very Good \\
\hline $\begin{array}{l}\text { Control of rate of } \\
\text { deliveries }\end{array}$ & 4.00 & Very Good & 4.00 & Very Good & 3.70 & Very Good \\
\hline $\begin{array}{l}\text { Verifying if deadlines } \\
\text { meet consumer } \\
\text { expectations }\end{array}$ & 4.00 & Very Good & 3.67 & Very Good & 3.70 & Very Good \\
\hline $\begin{array}{l}\text { Ability to reach target } \\
\text { consumers }\end{array}$ & 4.00 & Very Good & 3.67 & Very Good & 3.30 & Very Good \\
\hline $\begin{array}{l}\text { Communication on the } \\
\text { distribution process }\end{array}$ & 4.00 & Very Good & 3.89 & Very Good & 3.40 & Very Good \\
\hline $\begin{array}{l}\text { Accurate distributed } \\
\text { products }\end{array}$ & 4.33 & Very Good & 3.67 & Very Good & 3.80 & Very Good \\
\hline $\begin{array}{l}\text { Average Weighted } \\
\text { Mean }\end{array}$ & $\mathbf{4 . 0 0}$ & Very Good & $\mathbf{3 . 7 6}$ & Very Good & $\mathbf{3 . 5 8}$ & Very Good \\
\hline
\end{tabular}

In the distribution planning of Luntian MPC, the suppliers, members and management perceived that it has a very good distribution planning. According to Margaret Rouse, distribution planning is a systematic process to make the delivery of the goods more efficient by determining which goods, in what quantities and at what location are required to meet anticipated demand [16]. The goal is to minimize shortages and reduce the 
costs of ordering, transporting and holding goods. In addition to distribution planning of Luntian MPC, the management stated that they provide vehicle for the delivery of their products but the member on the other hand claim that they pick up their orders from Luntian using their own vehicle.

\section{CONCLUSION}

Based on the findings of the study, the researcher made the following conclusions:

1. On the degree of importance of the different supply chain management factors of the Luntian MPC in terms of developing supply chain management system, improved quality assurance and trust in Luntian MPC was considered very important.

2. In the performance of Luntian MPC in the supply chain management, most of the ratings are high except for location where to order/purchase in the inventory management, offer products that are highly reliable in the production management, space utilization for warehouse management, accurate count of stocks/accurate inventory information, inventory location (proper shelving) in the inventory management, machine efficiency for the manufacturing management.

\section{RECOMMENDATIONS}

Anchored on the conclusions which were derived from the findings of the study, the following recommendations were made:

1. Luntian MPC should make an effort to know all their customers. The firm must solicit suggestions on how to innovate and further improve according to what their customers need, want and demand.

2. Luntian MPC is known to have branches in different places but it offers different price compared to the main branch of Luntian in Tiaong, Quezon. With that, the branch should give the standardized price of the product like that of the main branch. Aside from that, the reason the member still placed their order in the main branch is because of the discount and the patronage points they get as a member in their purchase. In that case, Luntian members should gain that patronage points in other branches as well.

3. Luntian MPC should produce products that ensured product quality throughout the chain. Promoting product quality and safety can be done by making guidelines and rules starting from the procurement of raw materials down to the delivery of products to the end consumer.

4. The processes involved in ordering, production, warehousing, inventory, manufacturing and distribution should be standardized. Time limits for certain processes in the production should be set to ensure efficient utilization of time. Luntian MPC must standardize control. Control charts can be introduced and thoroughly explained on how to implement and how it should be followed.

5. The supplier should be reliable in delivering supply of raw materials to make sure that anytime of the day Luntian MPC's products are available for the consumers.

6. Luntian MPC have the proper milling machines that provide feeds, but the demand of the product is too high for one machine that they have. They should acquire more machine to be able to meet the rising needs of their members and consumers and if possible they should also adopt the advance technology of today like automation of the machines.

7. The Luntian MPC management and members should have an activity that will make them closer to each other and to build that rapport and trust within the cooperative.
8. The Luntian MPC should have a vehicle for delivery for members who do not have vehicle for the pick-up of their orders.

\section{REFERENCES}

[1] Handfield. 2011. What is supply chain management. Retrieved from https://scm.ncsu.edu/scm-articles/article/what-is-supply-chainmanagement

[2] Colayco, Francisco. 2009. Cooperatives. GMA News. Retrieved fromhttp://www.gmanetwork.com/news/story/opinion/ blogs/cooperatives

[3] Schill, A. 1995. Writing with precision: Cooperative office systems: concepts and enabling technologies. London: Prentice Hall.

[4] Top 5 Benefits of Supply Chain Management That will Double Your Business https://solutiondots.com/blog/benefits-of-supply-chainmanagement.html

[5] Greenlight. 2014. Supplier management relationship Retrieved from https://www.greenlight-itc.com/importance-supplier-relationshipbusiness/

[6] Zigiaris. 2000. Supply chain management. Retrieved from http://www.adi.pt/docs/innoregio_supp_management.pdf

[7] Valérie, B.D., Henninger, M.C., Assâad, E.A. 2012. The Relationship Between Members Trust and Participation in the Governance of Cooperatives: The Role of Organizational CommitmentRetrieved from https://www.ifama.org/resources/Documents/v15i1/Didier-HenningerAk remi.pdf

[8] Hult, T., Closs, D.J. 2014. Writing with precision: Global Supply Chain Mgts Leveraging process, measurement and tools for strategic corporate advantages. McGraw-Hill Education. U.S.A

[9] Jacobs, F.R. 2008. Writing with precision: Operations and Supply Management- The Core. McGraw-Hill International Edition. U.S.A

[10] Rouse and Gibilisco, 2009. Order management. Retrieved from $\mathrm{http} /$ /searchfinancialapplications.techtarget.com/definition/ordermanagement

[11] Writing with precision: State of the Art and Abstract Bibliography 2008. Supply Chain Management in the Philippines. University of Philippines Los Banos.

[12] Webster S. 2008. Writing with precision: Principles and tools for Supply Chain Management. McGraw-Hill/ Irwin International Edition. Boston, U.S.A

[13] Bowersox, D.J., Closs, D.J. 2009. Writing with precision: SupplyChain Logistics Managements (4th ed.). McGraw-Hill International Edition. U.S.A

[14] Steveson, W.J. 2009. Writing with precision: Operation Management (10th ed.). McGraw-Hill International Edition. U.S.A

[15] Berry, W.L., Vollman, T.E. 2011. Writing with precision: Manufacturing Planning and Control (6th ed.). McGraw-Hill International Edition. U.S.A

[16] Frederick Ross, Distribution Planning and Control: Managing in the Era of Supply Chain. Retrieved from https://books.google.com.ph/books?id=Z4LuBwAAQBAJ\&pg=PA244\& lpg=PA244\&dq=effective+distribution+planning\&source=bl\&ots=s16Eca uLz8\&sig=9w92ZdLNYhMmUX0uFoPEW1Eix8U\&hl=fil\&sa=X\&ved=0ahU KEwiY7uyJ9s7SAhXKXrwKHdNkBbsQ6AEIPTAE\#v=onepage\&q=effectiv e\%20distribution\%20planning\&f=false. 